\title{
ArcheoSciences
}

Revue d'archéométrie

\section{Analytical Investigations of Disintegrated Granite Surface from the Un-finished Obelisk in Aswan}

Enquêtes analytiques de la surface de granit désagrégé de l'Obélisque non fini à Assouan

\section{A. El-Gohary}

\section{OpenEdition}

Journals

\section{Electronic version}

URL: https://journals.openedition.org/archeosciences/2909

DOI: 10.4000/archeosciences.2909

ISBN: 978-2-7535-1849-0

ISSN: $2104-3728$

\section{Publisher}

Presses universitaires de Rennes

\section{Printed version}

Date of publication: 30 April 2011

Number of pages: $29-39$

ISBN: 978-2-7535-1847-6

ISSN: $1960-1360$

\section{Electronic reference}

M. A. El-Gohary, "Analytical Investigations of Disintegrated Granite Surface from the Un-finished Obelisk in Aswan", ArcheoSciences [Online], 35 | 2011, Online since 30 April 2013, connection on 28 February 2022. URL: http://journals.openedition.org/archeosciences/2909 ; DOI: https://doi.org/ 10.4000/archeosciences.2909 


\title{
Analytical Investigations of Disintegrated Granite Surface from the Un-finished Obelisk in Aswan
}

\author{
Enquêtes analytiques de la surface de granit désagrégé de l'Obélisque \\ non fini à Assouan
}

\author{
M. A. EL-GOHARY*
}

\begin{abstract}
The deterioration of natural stone monuments is subject to different external reasons that take place through different weathering factors, in addition to other several factors concerning the stone itself "internal reasons" mainly pore structure and permeability index. All of these factors lead to the formation of altered surface layers, then damaging the original stone components. Here, red weathering, one of the most aggressive deterioration forms affecting one of the most famous archaeological sites in the world (Un-finished Obelisk in Aswan) was investigated and evaluated through different analytical techniques. Binuclear Microscop and SEM were used to evaluate the optical and morphological features of the highly deteriorated samples. Moreover EDX and XRD techniques were used for defining the chemical and mineralogical compositions of collected samples. Lastly, ArcGIS program was used as a tool for simulation description of red weathering symptom to evaluate their aggressive roles in the deterioration processes affecting the object. Our results proved that there are some changes in the granite regarding essential elements with high percentages of $\mathrm{SiO}_{2}, \mathrm{Al}_{2} \mathrm{O}_{3}$ and $\mathrm{Fe}_{2} \mathrm{O}_{3}$ especially in affected zones. In addition, increasing the weathering products, such as, microcrystalline matrix and salty products (tosudite, kaolinite, illite and gypsum) defined and calculated both in affected and none affected areas. Finally, calculation of the etching volume of sample and corroded percentages were conducted.
\end{abstract}

Résumé : La détérioration des monuments en pierre naturelle est soumise à différentes raisons externes qui passent par différents facteurs d'altération, en plus de plusieurs autres facteurs concernant la pierre elle-même "raisons internes" essentiellement la structure des pores et l'indice de perméabilité. Tous ces facteurs conduisent à la formation des couches de surface altérée, puis détruisent les composants de la pierre originale. Dans le présent document, "l'altération rouge ", l'une des formes les plus agressives affectant l'un des plus célèbres sites archéologiques du monde entier: l'Obélisque non finis à Assouan (Haute-Egypte) a été étudiée par différentes techniques analytiques. La microscopie optique et le MEB ont été utilisés pour évaluer les caractéristiques optiques et morphologiques des échantillons fortement détériorés. En outre, l'analyse élémentaire par EDX et la diffraction des rayons X (XRD) ont été utilisées pour définir la composition chimique et minéralogique des échantillons prélevés. En outre, le programme ArcGIS a été utilisé comme un outil de simulation pour la description de l'altération rouge afin d'évaluer son rôle dans le processus de détérioration qui affecte notre objet. Nos résultats ont montré quelques changements dans le granit au niveau des éléments majeurs ( $\mathrm{S}$, Al et $\mathrm{Fe}$ ) notamment dans les zones touchées. Les produits ont augmenté intempéries telles que la matrice microcristalline et produits salés; Tosudite, Kaolinite, Illite et de Gypse, en plus définir et calculer les zones touchées et non touchées (to be reformulated, hardly understandable). Enfin, le calcul du volume de gravure de l'échantillon et les pourcentages corrodés ont été menés.

Keywords: Granite, Deterioration, Weathering, Red Spots, EDX, XRD.

Mots clé : Granit, Détérioration, Altération, Des taches rouges, EDX, XRD.

*Conservation dept., Faculty of Arts, Sohag Univ., Egypt.(m_1968_algohary@yahoo.com) 


\section{INTRODUCTION}

The deterioration of natural stone monuments is subject to different external reasons (Auger, 1991) through different weathering factors which are considered important phenomena especially with the presence of salty and moisten environments (Robert et al., 1992), in addition to other several factors concerning the stone itself, mainly pore structure and permeability index (Auger, 1996). Furthermore, the interactions between the atmosphere and invariably monumental stones lead to the formation of altered surface layers, producing damage to the original stone (Sabbioni, 1995), rocks and material exposed continually to physical, chemical and biological weathering processes (Fassina, 1991). Moreover, the degree and distribution of the types of observable stone deterioration in urban environments are often related to different patterns of wetting and drying cycles (Winkler, 1997; Chabas and Jeannette, 2001), in addition to the exposure of the stone surface to driven rain (Camuffo et al., 1983). Deterioration of granite has been less studied than that of other natural types of stones where the deterioration cycles affecting this type of stone caused the stone surface color to alter and become irregular then cause other weathering mechanisms to take place (Scheffer and Lesak, 2000).

The aim of this study is to define and evaluate the effects of a special kind of weathering form and its aggressive role affecting the un-finished obelisk which could lead to concealing it through time especially with aggressive environmental conditions dominating in its area. Un-finished obelisk (fig. $1-a, b)$ is one of the oldest Egyptian obelisks, which is the world's largest piece of stone ever handled; it is located in the Northern Quarry of Aswan (Stocks, 2003). It was made for Queen Hatshepsut 18th dynasty (Badawy, 2004; Whitman, 1992) between 1472 and 1458 (Del Testa et al., 2001) and left there because a crack was discovered which caused it to be abandoned. From an archaeological point of view, it is considered one of the most famous archaeological sites all over the world and it attests to the intelligence of the ancient
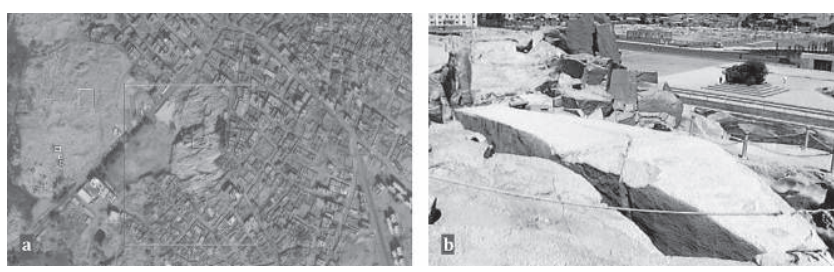

Figure 1: (See colour plate) a: general over view of obelisk site (after Google earth), b: the site of Un-finished obelisk.

Figure 1 : (Voir planche couleur) a: un aperçu général sur le site de l'obélisque (d'après Google Earth), b: le site de l'Obélisque non fini.
Egyptian architects and builders. It has been estimated to weigh 1168 tons and is 137 feet long (Cottrell, 1966). This obelisk is made of a local type of red coarse grained granite belonging to Aswan quarries which is characterized by normally pinkish color with abundant pink porphyroblasts, small feldspar crystals, quartz and dark ferromagnesians, in addition to small crystals of apatite. Also, it is generally hard and compact, but it is heterogeneous in its chemical and mineralogical composition, while its disintegration is useful to dating studies by luminescence (El-Shazly, 1954; Liritzis et al., 2008a, b). The obelisk is suffering from aggressive disintegration forms due to several factors in addition to aggressive environmental conditions particularly variation in air temperature, moisture values and different anthropogenic effects, in addition to the effects of seepage and leakage water due to several sources (El-Gohary, 2004). Moreover, the effects of the disposal of solid wastes (Sease, 1992) which lead to some chemical reactions with surface components of the obelisk. All of these factors lead to creation of some weathering forms such as:

Surface disintegration and micro-fissures, in addition to scale form, (fig. 2-a).

Surface oxidation and fading of stone blocks, (fig. 2-b).

After evaluating the visual appearances, deterioration symptoms and environmental situation dominating in the study area, it could be decided that the red spots or crusts are the major deterioration forms diffused on the surfaces of the obelisk, (fig. 3-a, b). It is one of the dangerous symptoms created by the weathering process and represents one of the deterioration phenomena related to rock bedding and rock minerals through external forces (El-Gohary, 2010; Kikuchi et al., 1998). Through specific studies done in the study area, the author can define the red weathering as "Soften red pimples participating on the obelisk surface created through the effect of washing and leaching of alkaline silicates by different sources of moisture, that lead to the accumulation of none affected and affected quartz grains resulted essentially
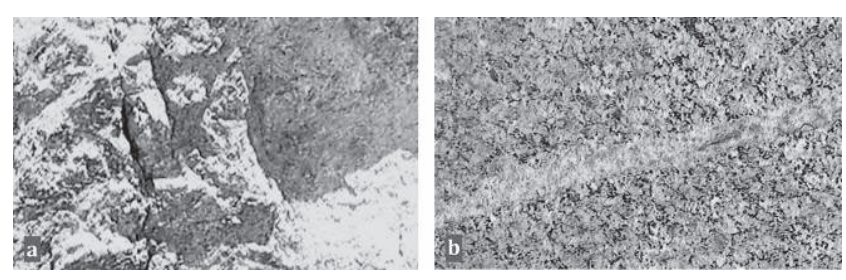

Figure 2: (See colour plate) Deterioration forms affecting the Granite of Un-finished obelisk a: surface disintegration, b: surface oxidation and salt efflorescence.

Figure 2: (Voir planche couleur) Les formes de détériorations qui affectent le Granite de l'Obélisque non fini a: la désintégration de surface, b: l'oxydation de surface et l'efflorescence de sel. 


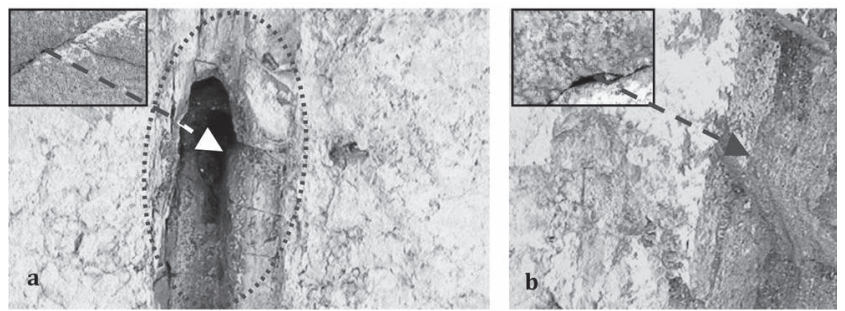

Figure 3: (See colour plate) a: red weathering form and leaching some chemical components, b: decaying, braking down and transforming the essential components of granite structure.

Figure 3 : (Voir planche couleur) Forme de désagrégation rouge et lixiviation de certains composants chimiques, b: décomposition, et transformation des composantes essentielles de la structure de granite.

from continuously alternating actions between drying and wetting cycles". Furthermore, this form represents a special form that characterizes not only the obelisk body but also some stone blocks in surrounding area. However, the spatial distribution of the red weathering crusts affecting the body of the obelisk appears to be strongly influenced by its position, direction and speed of the wind, and alternative cycles of drying and wetting, in addition to exposure to other environmental conditions as discussed before (Begonha and Sequeira Braga, 1996) in a similar case. These spots diffuse on the surfaces of the obelisk particularly beside the bedrock and are characterized by some special features as presences of some mafic composition such as biotite and look as red spots with size ranging from some millimeters to few centimeters (Bugini, 2000). Moreover, the development of these spots especially with abundance of different sources of moisture especially ground water finally lead to some chemical and mineralogical transformations in addition to forming some types of clay minerals such as tosudite, illite, montmorillonite and kaolinite (Lodding and Strum, 1968; Newman, 1987; Sayin, 2007). These minerals belong to hydrous phyllosilicates principally composed of $\mathrm{Al}, \mathrm{Mg}, \mathrm{Fe}$ (II) and $\mathrm{Fe}$ (III), in addition to less frequently other ions as $\mathrm{Ni}$, and larger cations such as $\mathrm{K}, \mathrm{Na}$ and $\mathrm{Ca}$ (Brindley and Lemaiter, 1987 ) which play a significant role in the crystallization processes of clays (El-Gohary, 2009; Velde and Meunier, 1987).

\section{Materials AND ANALYTICAL METHODS}

Three types of granite samples (sheets, disaggregated grains and powdered materials) which represent the various grades of deterioration in the obelisk body were collected according to (NORMAL 3/80, 1980). These samples were studied and investigated by several scientific techniques such as Digital
Caliper, (DC) model Höchste Nesspräzision which was used to measure the crusts depth. Also, two types of microscope (digital binuclear model Bausch and Lomb attached to Jenalux 20 light unit, (DBM) and JSM 5300 scanning electron microscope with acceleration voltages of $10-30 \mathrm{kV}$, (SEM) were used to evaluate the optical and morphological features of the highly deteriorated samples of red weathering spots and superficial crusts collected from different points of the obelisk. Furthermore, these crusts were analyzed by EDX device model EDAX-Oxford unit and XRD instrument model 6000-Shimazu X-ray diffractometer using $\mathrm{Cu}$ $\mathrm{k} \alpha$ for defining their chemical and mineralogical compositions. In addition to the ArcGIS program was used as a tool for simulation description of red weathering symptoms to evaluate their aggressive roles in the weathering and deterioration processes affecting the present study area.

\section{Results}

\section{Thickness of Red Crusts by Digital Caliper (DC)}

Red crust samples were measured using DC to evaluate the rates of their roots depth' under the affected surfaces. These depth are more than $2.5 \mathrm{~cm}$ in sample 1, between 1.8 and $2 \mathrm{~cm}$ in sample 2, from 1.6 to $1.8 \mathrm{~cm}$ in sample 3 , between 1 and $1.2 \mathrm{~cm}$ in sample 4, from 0.8 to $1 \mathrm{~cm}$ in sample $5 \mathrm{~cm}$, and finally between 0.4 and $0.6 \mathrm{~cm}$ in sample (fig. 4).

\section{Optical Observation by Digital Binuclear Microscope (DBM)}

Different grades of red weathering were observed, captured and documented using DBM. These symptoms varied according to their rate into several grades such as:

- Beginning of the chemical reactions, dissolution processes, (fig. 5-a).

- Initial creation of small pimples and spots characterized by red color (fig. 5-b).

- Completely forming the clear and prominent red crusts or spots on the stone surfaces (fig. 5-c).

\section{Morphological Investigation by SEM}

According to the scientific method presented by (Gilkes, 1980) granite surface morphology evaluated by SEM and the obtained results proved that the obelisk had been strongly affected through different weathering factors which lead to some deterioration effects such as: 


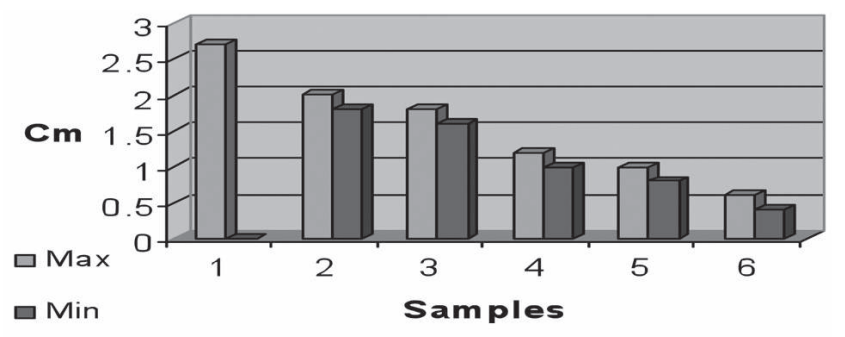

Figure 4: Showing thickness of red crusts by digital caliper. Figure 4 : Montrant l'épaisseur des croûtes rouges par l'étrier numériques

- Degradation and breaking forms in addition to bridging gaps between grains, (fig. 6-a).

- Particles accumulating composed of some species of clay minerals and salts, (fig. 6-b).

- Creation of red crusts, micro-fissures and other deterioration forms, (fig. 6-c).

\section{Chemical Analysis by EDX}

The chemical analyses of red weathering spots (diameter average between $2.64-40.22 \mathrm{~mm}$.) made by EDX proved that the different ratios of elemental oxides are highly affected but with different grades according to place and depth of weathering spots, these results are listed in Table 1, and they could be summarized as follow:

The crust samples are composed essentially of $(\mathrm{Na}, \mathrm{Mg}$, Al, Si, P, S, K, Ca and Fe), (fig. 7-a).

Elemental oxides averages of the crust samples are $\left(\mathrm{SiO}_{2}\right.$, $38.64 \%),\left(\mathrm{Al}_{2} \mathrm{O}_{3}, 36.31 \%\right)(\mathrm{MgO}, 2.68 \%),\left(\mathrm{K}_{2} \mathrm{O}, 3 \%\right)$ $(\mathrm{CaO}, 3.32 \%)$ and $\left(\mathrm{Fe}_{2} \mathrm{O}_{3}, 14.40 \%\right)$ (fig. 7-b).

Increase in the average ratios of both $\mathrm{Al}_{2} \mathrm{O}_{3}$ as an essential component of clay minerals and $\mathrm{Fe}_{2} \mathrm{O}_{3}$ (Hematite) as an essential component of pigmented minerals over the ideal limit compared with un-affected granite surface, which is essentially composed of $\left(\mathrm{SiO}_{2}, 60.03 \%\right),\left(\mathrm{Al}_{2} \mathrm{O}_{3}, 15.14 \%\right)$ $(\mathrm{MgO}, 3.68 \%),\left(\mathrm{K}_{2} \mathrm{O}, 2.86 \%\right)(\mathrm{CaO}, 5.19 \%)$ and $\left(\mathrm{Fe}_{2} \mathrm{O}_{3}\right.$, 11.80\%) (El-Gohary, 1996).

Presence of the minor components of some kinds of salty crusts which could be distinguished as $\left(\mathrm{Na}_{2} \mathrm{O}, 0.8 \%\right)$ and $\left(\mathrm{SO}_{3}\right.$, $0.65 \%)$ that is due to the aggressive effects of alternative processes between several sources of groundwater and drying cycles "washing and drying", in addition to $\left(\mathrm{P}_{2} \mathrm{O}_{5} 0.23 \%\right)$.

\section{Mineralogical Examination by XRD}

XRD results showed that the components of red spots consist of different phases of minerals which can be distinguished as follows:

Assembly of microcrystal of Sanidine $\left[(\mathrm{K}, \mathrm{Na}) \mathrm{AlSi}_{3} \mathrm{O}_{8}\right]$, Anorthite $\left[\mathrm{CaAl}_{2} \mathrm{Si}_{2} \mathrm{O}_{8}\right]$, Quartz $\left[\mathrm{SiO}_{2}\right]$, Oligioclase $[(\mathrm{Na}, \mathrm{Ca})$ $\left.(\mathrm{Si}, \mathrm{Al})_{4} \mathrm{O}_{8}\right]$ and Biotite $\left[\mathrm{K}\left(\mathrm{Mg}, \mathrm{Fe}^{++}\right)_{3} \operatorname{AlSi}_{3} \mathrm{O}_{10}(\mathrm{OH})_{2}\right]$, as essential minerals of granite especially in semi-affected areas.

Other major phases are disseminated in this microcrystalline matrix as weathering and salty products especially in highly affected areas such as Montmorillonite $\left[(\mathrm{Al}, \mathrm{Mg})_{8}\right.$ $\left(\mathrm{Si}_{4} \mathrm{O}_{10}\right)_{4}(\mathrm{OH})_{8} .12 \mathrm{H}_{2} \mathrm{O}$ ], Illite [K-Na-Mg-Fe-Al-Si-O$\left.\mathrm{H}_{2} \mathrm{O}\right]$, in addition to other minor phases as Chlorite [ $(\mathrm{Mg}$, $\left.\mathrm{Fe})_{3}(\mathrm{Si}, \mathrm{Al})_{4} \mathrm{O}_{10}(\mathrm{OH})_{2} \cdot(\mathrm{Mg}, \mathrm{Fe})_{3}(\mathrm{OH})_{6}\right]$, Tosudite $\left[\mathrm{Na}_{0.3} \mathrm{Al}_{6}\right.$ $\left.(\mathrm{Si}, \mathrm{Al})_{8} \mathrm{O}_{20}(\mathrm{OH})_{10} \cdot 4 \mathrm{H}_{2} \mathrm{O}\right]$, and Gypsum $\left[\mathrm{CaSO}_{4} \cdot 2 \mathrm{H}_{2} \mathrm{O}\right]$, Hematite $\left[\mathrm{Fe}_{2} \mathrm{O}_{3}\right]$ and two of these crystalline phases are shown in (fig. 8-a and b).

\section{GIS Modeling Investigation}

ArcGIS technique (Park et al., [www.isprs.org]) was used for evaluating the size of etching of stone fragments affected
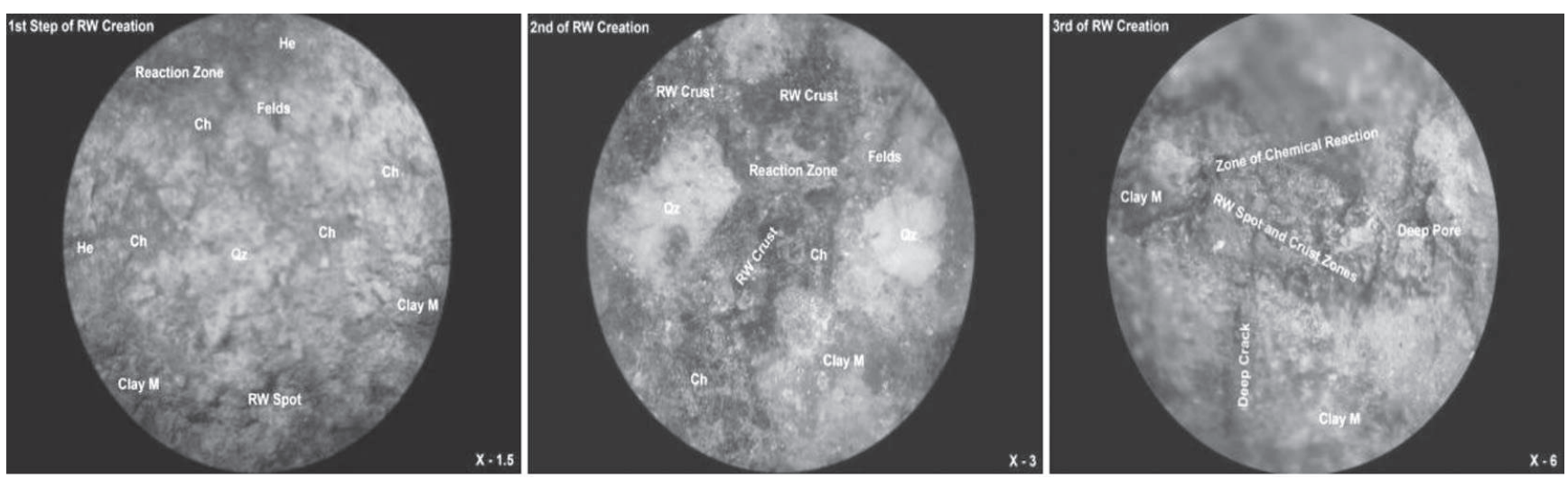

Figure 5: (See colour plate) Digital binocular photos showing the grade of red weathering crusts affecting granitic samples.

Figure 5: (Voir planche couleur) Photo par binoculaire numérique montrant le grade de croûtes rouges intempéries qui affectent les échantillons granitiques. 

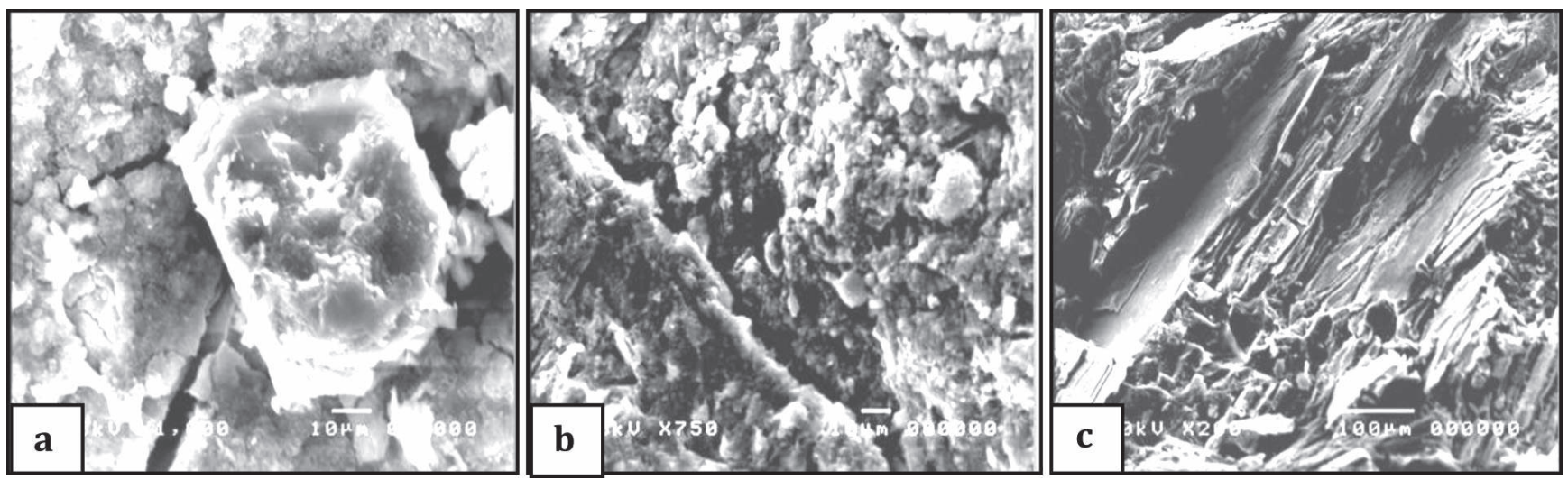

Figure 6: SEM photomicrograph showing grade of red weathering crusts affecting granitic samples.

Figure 6 : Photomicrographie montrant le grade de croûtes rouges intempéries qui affectent les échantillons granitiques.

\begin{tabular}{|c|c|c|c|c|c|c|c|c|}
\hline Elements & $\mathrm{S} 1$ & $\mathrm{~S} \mathrm{2}$ & $\mathrm{S} \mathrm{3}$ & $\mathrm{S} 4$ & $\mathrm{~S} 5$ & S 6 & Average & STDV \\
\hline $\mathrm{Na}_{2} \mathrm{O}$ & 00.00 & 00.00 & 04.80 & 00.00 & 00.00 & 00.00 & 00.80 & 01.96 \\
\hline $\mathrm{MgO}$ & 00.00 & 00.00 & 02.59 & 08.62 & 02.43 & 02.43 & 02.68 & 03.16 \\
\hline $\mathrm{Al}_{2} \mathrm{O}_{3}$ & 39.39 & 66.78 & 15.63 & 30.84 & 33.61 & 31.61 & 36.31 & 16.88 \\
\hline $\mathrm{SiO}_{2}$ & 37.35 & 25.98 & 44.30 & 40.40 & 42.56 & 41.23 & 38.64 & 06.62 \\
\hline $\mathrm{P}_{2} \mathrm{O}_{5}$ & 00.00 & 00.00 & 01.35 & 00.00 & 00.00 & 00.00 & 00.23 & 00.55 \\
\hline $\mathrm{SO}_{3}$ & 00.00 & 00.00 & 02.12 & 00.00 & 00.90 & 00.90 & 00.65 & 00.84 \\
\hline $\mathrm{K}_{2} \mathrm{O}$ & 03.17 & 02.25 & 09.22 & 00.00 & 00.00 & 03.33 & 03.00 & 03.39 \\
\hline $\mathrm{CaO}_{\mathrm{Fe}} \mathrm{O}$ & 02.11 & 00.00 & 05.80 & 05.63 & 03.19 & 03.19 & 03.32 & 02.19 \\
\hline $\mathrm{Sum}$ & 17.98 & 04.98 & 14.20 & 14.52 & 17.32 & 17.32 & 14.40 & 04.87 \\
\hline
\end{tabular}

Table 1: Elemental average of investigated samples by EDX.

Tableau 1 : La moyenne élémentaire des échantillons d'étude par EDX.

by red weathering crusts. As the stone samples represent cubes, the total volume of etched sample is (height $\times$ length $x$ width), (fig. 9-a). Different heights on the etched surface were taken that cover uniform spaces of the stone's surface. By interpolating these points using the method of Inverse Distance Weighting (IDW) in a GIS environment, a layer that represents the height was obtained $(\mathrm{H})$. This layer is basically a Raster-GIS layer where each pixel in it represents the height of the etching in the same pixel. Thus the etching volume (EV) of a sample would follow the equation

$$
E V=\sum_{i=1}^{n} H_{i} \times X
$$

$\boldsymbol{E} \boldsymbol{V}=$ etching volume of the sample in $\mathrm{mm}^{3}$.

$\boldsymbol{H}=$ interpolated Raster layer of etching heights in $\mathrm{mm}$.

$X=$ surface area of the stone cube in $\mathrm{mm}^{2}$.

$\mathrm{n}=$ number of interpolated points.
For example, the etching volume of the above demonstrated sample equals $47.15 \mathrm{~cm} 3$; representing $43.32 \%$ of the total volume. The total volume of the sample without affection it is then equals $108.83 \mathrm{~cm}^{3}$ "surface area of the cube times the height", (fig. 9-b). The mesh of the sample was draped through stony features to visualize the influence of red weathering symptoms on surface morphology of stone as shown in (fig. 9-c)

\section{Discussion}

Several scientific studies conducted on the deterioration of granitic monuments proved that the chemical weathering is the essential mechanism of deterioration affecting this type of stone (Power and Smith, 1994; Sweevers et al., 1995; Schiavon, 1996). Red weathering crusts and their 

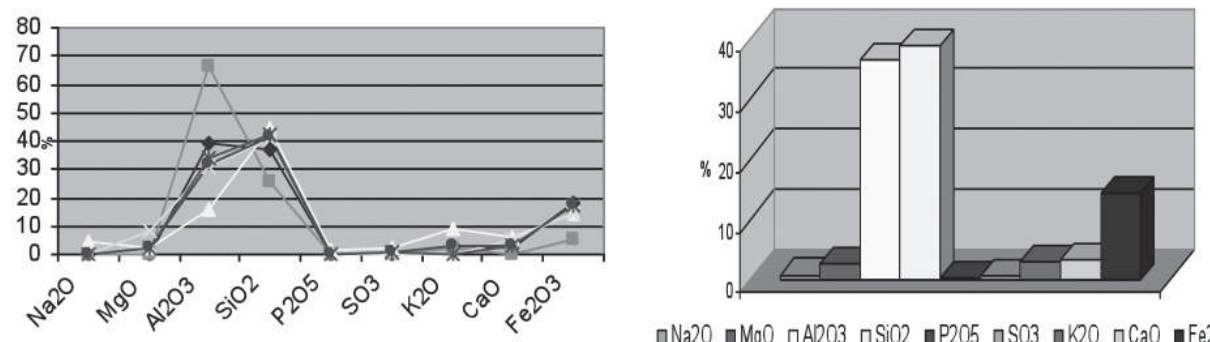

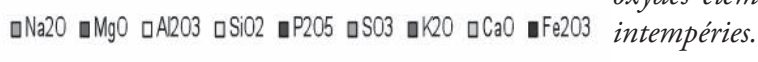

Figure 7: (See colour plate) a: EDX analytical data of red weathering crusts, b: average of elemental oxides of red weathering crusts.

Figure 7 : (Voir planche couleur) a: EDX de données analytiques de croûtes rouges intempéries, b: moyenne des oxydes élémentaires de crồtes rouges



Figure 8: Models of XRD patterns of red weathering crusts.

Figure 8: Les modèles de XRD modes de croûtes rouges intempéries.

harmful effects are the most severe deterioration symptoms affecting the unfinished obelisk. The components of these crusts were carefully investigated through various techniques described above, which proved that all of these crusts are due to some deterioration mechanisms, mainly drying and wetting alternative cycles (Allison and Palmer, 1980), in addition to some aggressive hydration processes that lead to the presence of iron hydroxide in feldspar minerals as previously confirmed by (Sidraba et al., 2002) and the presence of other mechanisms such as salty crystal growth and effects of organic deposition (El-Gohary, 2004). Furthermore, it could be emphasized that these crusts are characterized by the presence of multi-types of clay minerals pigmented by red color through iron oxide. These crusts have different thickness that varied between more than 2.5 to $0.4 \mathrm{~cm}$, which are essentially are due to weathering grads and the moisture contents that vary from place to another along the site. Furthermore, it could be argued that these crusts are characterized by low strength and deep weathering values that are due to the alteration of biotite leading finally to this type of weathering; these results are in agreement with others (Stierman and Healy, 1984). Based on surface and morphological descriptions by DBM and SEM, it could be

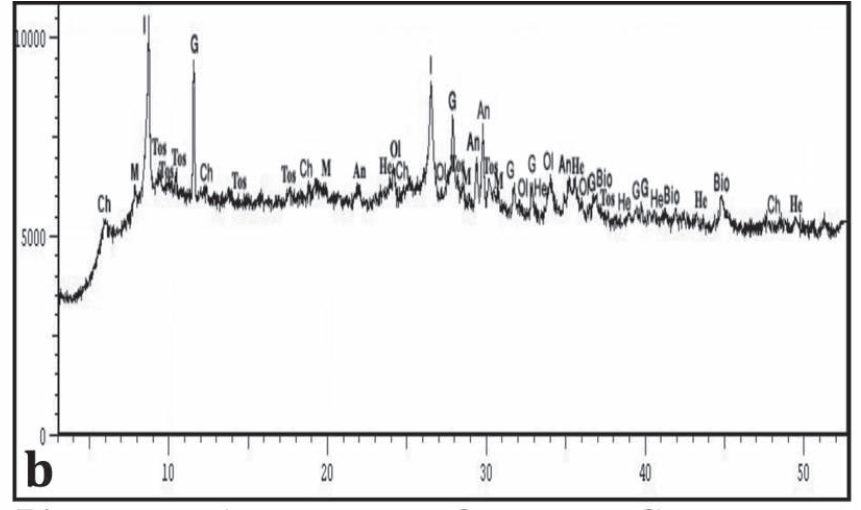

Bio=Biotite, $\mathbf{A n}=$ Anorthite, $\mathbf{Q}=$ Quartz, $\mathbf{G}=$ Gypsum noticed that red weathering affecting the un-finished obelisk had undergone drastic and un-controllable deterioration mechanisms because of the natural and environmental conditions dominating in the study area.

Optically, the existence of different colors and un-preferable morphological features of weathering products accumulated on some points of the obelisk surface is mostly due to the effects of chemical weathering cycles. These cycles are characterized by different deterioration mechanisms such as chemical reaction, transformation and etching. Accordingly, it could be said that these cycles were generated through chemical reactions, dissolution processes and disintegration of the main granite components, (fig. 4-a). These reactions lead to the degradation and breaking of intra-crystalline fractures of quartz grains, great extinction of cracks in feldspar crystals and pseudo-hexagonal plates of detrital kaolinite, in addition to bridging gaps between open cleavage planes in mica plates (fig. 5-a). On one hand, the beginning of the creation of some small pimples of red spots affecting the granite surfaces is mostly an outcome of aggressive washing and leaching cycles affecting alkaline silicates in addition to the increase of the chemical transformations cycles that essentially led to compose some types of clay minerals as 
kaolinite, montmorillonite, illite and tosudite (fig. 4-b). On the other hand, chlorite which had been present as surface accumulations outcome of different chemical weathering mechanisms, effects of wetting and drying cycles and the presence of some spots composed of hematite as an essential surface component of red crusts. This is essentially due to the losing of black mica its ferrous-ferric from lattice at the beginning of weathering process and soon precipitates as rust halos around the mica flacks, (fig. 5-b) (Winkler, 1997; Lee et al., (2003).

Moreover, the forming of the clear and prominent red spots on the stone surfaces led to some internal micro-fissures and external cracks which may develop other deterioration forms as scaling or flaking, (fig. 4-c). Consequently, it could be argued that the final red weathering crusts and their related deterioration forms and micro-fissures are essentially direct results of heavy external stress and internal strains dominating between all mineralogical components of granite particularly quartz and feldspar grains (Baptista, 2006), (fig. 5-c). Within the same context, different chemical analytical techniques, qualitative and quantitative, represented in (fig. 6 and 7) proved that these crusts brown or red resulted from aggressive deterioration factors dominating in the study area through oxidation, kaolinization and rusting mechanisms, in addition to other chemical changes. Theses crusts or rusting spots are essentially composed of some species of clay minerals as main components and iron oxide (hematite) as colorants or pigmented materials that resulted from the different iron sources dominating either in the mineralogical composition of stone itself or as an essential element that characterize the domestic water sources in the study area (El-Gohary, 2004). The existence of Fe ion (the major component of hematite) may be due to the chemical combination with atmospheric oxygen to form rust (iron oxide), especially in the presence of some sources of moisture which accelerate the rusting process. In addition to that, Fe oxides in rocks formed during an earlier weathering cycle may also give rise to soluble Fe (II) species under reduction conditions, or to soluble Fe (III) species through complex formation with organic compounds that finally lead to the rusting symptoms. These symptoms are affected by several factors such as time; rate and degree of hydrolysis cycles, ageing conditions dominated $\mathrm{pH}$ and chemical environments, as reported by (Taylor, 1987), where all Fe oxides can form under humid conditions in all climatic zones as reviewed before (Segalen, 1971), or may be present as an essential component of kaolin group (Newman and Brown, 1987). In our case, Fe oxides are precipitated mostly at the edges of stone surfaces as a direct result of natural weathering and dissolution processes affecting some iron bearing compounds such as biotite grains especially with the presence of some of severe oxidation and hydration cycles, where air and water break down ferrous silicate as biotite and convert their ferrous iron to ferric oxide Red spots, thus changing the original colors to red or brown ones as discussed before by (Murakami et al., 2003; Murakami, et al., 2004). Furthermore, iron which was expelled from the biotite lattice was not removed from the grain in early stages of weathering and interlamellar crystallization of iron oxyhydroxide could take place. Then the thin sheets of iron oxide subsisted during the kaolinization process leading to reddish or brownish stains (Bisdom, et. al., 1982). From a specialized point of view, it could be seen that these spots are characterized by transient index where they are easy to remove by the effects of air currents or to wash by the water currents. On the other hand, the presence of different types of clay minerals (tosudite, illite, montmorillonite and kaolinite) owing to the feldspar alteration processes which can lead to precipitation of various types of aluminous and alumino-silicate compounds (Guven et al., 1982; Barros, 2000). These types of silicates are composed either residually or primarily and lead to the argillization of granitic rocks producing several types of clay minerals (Zalba, 1982) according to the dominant environmental conditions especially $\mathrm{pH}$ values (Dontsova and Bigham, 2005; Chen, 1990) that play an important role both in controlling many chemical reactions and substances solubility (Ollier, 1975). Kaolinite usually develop in an acidic environment or in a neutral environment where intense leaching processes prevail; montmorillonite forms in the presence of certain alkalis and alkaline earths and illite which is the dominant clay mineral in marine sediments (Murray, 1953). Thus, the presence of these minerals in our case is mostly due to the synergetic effects dominating in the study area that led to decomposition processes which include hydrolysis, hydration, carbonation and oxidation cycles that finally led to create some of these minerals according to the following formulas.

Therefore, kaolinite which occurs as aggregates or single veins is the dominant end product of weathering processes affecting potassium feldspar through the kaolinization process as reported previously by (Parham, 1969; Jolicœur et al., 2000) in similar cases. On the other hand, illite may have been deposited after its formation by the weathering of silicates, principally feldspar minerals (Smith, 1998; White and Brantley, 2003). Furthermore, the presence of montmorillonite is essentially due to several weathering processes, and is considered one of the alteration products of plagioclase feldspars resulted from an albitization process then alteration to kaolinite depending on suitable conditions particularly lower temperature (Deer et al., 1988), 


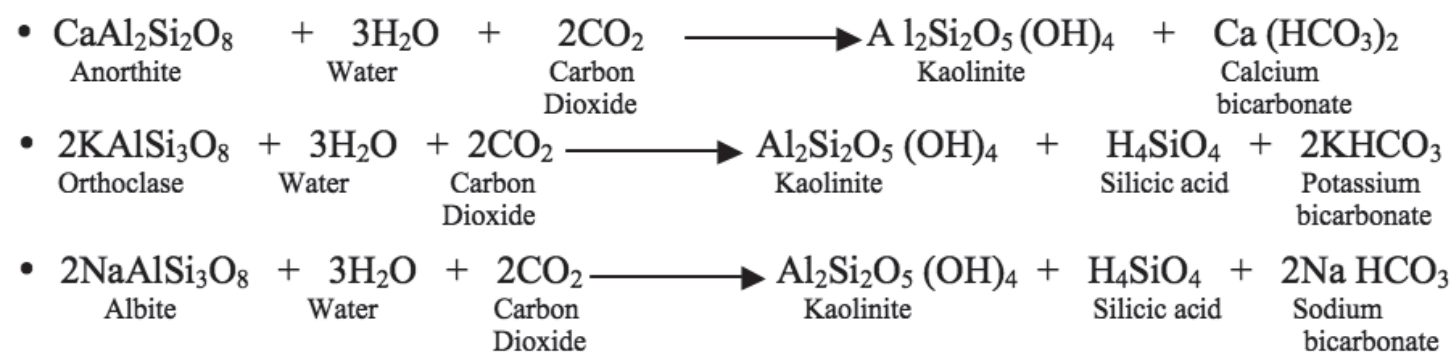

climate, topography and the leaching degree (Keller, 1970; Huang, 1974). Moreover, it could be emphasized that the presence of some accumulated particles of chlorite (Suggate and Waiters, 1991) within the crust composition as one of the most weathering products of granitic rocks is due to alteration processes affecting the ferromagnesians represented by dark pleochroic biotite (Szadorski et al., 2007), which is often more or less altered to light green of fine particles (Bisdom et al., 1982). This mineral is also characterized by a great range in chemical composition which has been reflected through variation in its physical and optical properties as discussed previously (Klein and Hurlbt, 1985). Along these lines, it could be said that the presence of Tosudite as one of the principal clay minerals (Shimoda, 1969) is mostly created in association with di-octahedral chlorite and serpentine during acid hydrothermal alteration, when the temperature decreased below $350^{\circ} \mathrm{C}$ as argued before (Środoń, 1999). In our case, tosudite is due to the aggressive alteration processes dominating in the study area which affect the other types of clay minerals through complex chemical and hydrothermal reaction (Daniels and Altaner, 1990).

Finally, it can be argued that the existence of gypsum as a salty weathering product is essentially due to different severe deterioration factors and mechanisms (Borrelli, 1999) that the obelisk suffers from such as the emission of car exhaust and other industrial activities (El-Gohary, 2007). These effects play an important role in the acceleration of weathering processes affecting the calcite flagstones, layers of lime mortar or other sources of calcium, especially in the
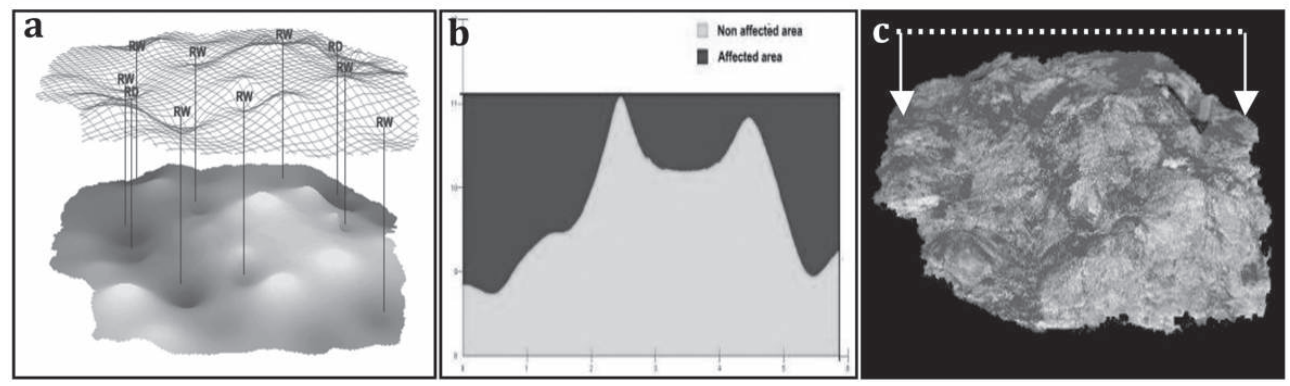

presence of sufficient amount of moisture as argued before by (O'Brien et al., 1995; McKinley et al., 2001), besides the aggressive alternative cycles between drying and wetting (Lal Gauri and Yerrapragada, 1996). In addition to the effects of sulphation mechanisms of other indirect factors dominating in the study area as some species of microorganism which finally lead to accelerating the rate of monumental stone degradation (El-Metwally and Ramadan, 2005).

Through analysis of different GIS, (fig. 9-a, b, c), it could be noticed that granite surface had been actually affected by one of the most aggressive deterioration forms through the previous time especially in the last 50 years. These could be noticed through some of different deterioration features such as etching, granular disintegration and surfaces decomposition. These forms actually appeared through sever mechanisms that had been increased because of the development of several industrial activities in the study area particularly iron industrial activities in addition to quarrying different kind of stones. Furthermore, it could be said that the simulating features of red weathering crusts are considered important methods that should be used for studying the changes in color and relief of each mineral grain dominating in the stone surface. Thus it could be useful for further identification of specific characteristic and behavior of mineral against weathering factors specially the etching index of the samples. We can also see that if more measurements are conducted after further weathering, each volume

Figure 9: (See colour plate) a: mesh of red weathering spots affected granite surface, b: profile of affected and non-affected granite surface, c: profile mid section and visualization of stone surface. Figure 9: (Voir planche couleur) Un maillage de taches rouges intempéries qui affectent la surface de granite, b: profil de la surface de granite affecté et non affecté, c: profil de mi-section et visualisation de la surface de pierre 
loss of mineral grain can be easily defined and calculated and then used for further analysis of differential weathering rate of each mineral, which leads to quantitative assessment of durability of important stone monuments. The investigation is useful to dating of similar rocks by optical luminescence by avoiding sampling from reported weathered areas (Liritzis et al., 2008 $)$.

\section{Conclusion}

The deterioration of granitic stone materials is a complex process caused by the interaction between numerous correlated factors such as climatic region, urban pollution and properties of the materials that finally lead to the chemical, physical/mechanical and biological weathering. Moreover, the behavior of the construction materials under weathering conditions is predicted by the object's design and constructive elements. On the other hand, there are some specific weathering forms affecting different granitic monuments depending on the surrounding environmental conditions such as red crusts dominating our case study characterized by aggressive alternative drying and wetting cycles, in addition to other deterioration factors either chemical or biological closely linked to weathering rates of silicate minerals. Consequently, it could be emphasized that the special weathering form which characterizes our monuments is due to all of these factors and their related mechanisms; it is composed essentially of complex types of clay minerals pigmented by iron oxide. All of these aforementioned factors require some conservation procedures to protect monuments through different scientific strategic plans that contain several preventive and interventive actions.

\section{Acknowledgment}

I'm in great debt to Dr. Al-Shorman, A. who helped and reviewed the interpretation of GIS part.

\section{References}

Allison, I. S. and Palmer, D. F., 1980. Geology: the science of a changing earth, NY.

Auger, F., 1996. Durabilité des pierres calcaires utilisées dans le patrimoine architectural, Mém. Soc. Géol., 169: 415-420.

Auger, F., 1991. Vieillissement par altération atmosphérique des matériaux de construction-etude comparative in situ et en simulation. International symposium on the deterioration of building materials, La Rochelle, 115-128.
Baptista-Neto, J. A., Smith, B. J., Mcallister, J. J., Silva, M. A. M. and Castanheira, F. S., 2006. Surface modification of a granite building stone in central Rio de Janeiro, Annals of the Brazilian Academy of Sciences, 78, (2): 317-330.

Barros, L. A., 2000. Modes and mechanisms of rock weathering. In Galan and Zezza, (eds.) $5^{\text {th }}$ international symposium on the conservation of monuments in the Mediterranean basin, Seville, Spain, 3-6.

Begonha, A. and Sequueira Braga, M. A., 1996. Characterization of black crusts and thin black layers in granitic monuments: The role of air pollution. In Vicente, M. A. et al. (eds.) Degradation and conservation of granitic rock in monuments, European Commission, Brussels, 121-126.

Bisdom, E. B., Stoops, G., Delvigne, J. and Altemuller, H. J., 1982. Micro-morphology of weathering biotite and its secondary products, Pedologie, XXXII, (2): 225-252.

Borrelli, E., 1999. Salts, ARC laboratory handbook, 3, ICCROM, Rome.

Brindley, G. W. and Lemaiter, J., 1987. Thermal oxidation and reduction reactions of clay minerals. In Newman, A. C. D. (ed.). Chemistry of clays and clay minerals, Longman, UK, 319-322.

Bugini, R., Pavese, A., Borroni, S. and Folli, L., 2000. White granite used in Lombard architecture. In Fassina, V. (ed.) $9^{\text {th }}$ int. cong. On deterioration and conservation of stone, Volume I, Venice, Elsevier, 41-48.

Camuffo, D., Del Monte, M. and Sabbioni, C., 1983. Origin and growth mechanisms of the sulphated crusts on urban limestone. Wat Air Soil Pol, 19: 351-359.

Chabas, A. and Jeannette D., 2001. Weathering of marbles and granites in marine environment: petrophysical properties and special role of atmospheric salts, Environmental Geology. 40, (3): 359-368.

Chen, J. S., Cushman, J. H. and Low, P. F., 1990. Rheological behavior of Na-Montmorillonite suspensions at low electrolyte concentration, Clays and Clay Minerals, 38, (1): 57-62.

CNR-ICR, 1980. NORMAL 3/80, Rome.

CotTrell, L., 1966. Egypt, University of Michigan, USA.

Daniels, E. J. and Altaner, S. P., 1990. Clay mineral authigenesis in coal and shale from the Anthracite region, Pennsylvania, American Mineralogist, 75: 825-839.

Deer, W. A. Howie, R. A. and Zussman, J., 1988. An introduction to the rock-forming minerals, $15^{\text {th }} \mathrm{ed}$., Wiley, London.

Del Testa, D. W., Lemoine, F. and Strickland, J., 2001. Government leaders, military rulers, and political activists, Greenwood, NY.

Dontsova, K. M. and Bigham, J. M., 2005. Anionic polysaccharide sorption by clay minerals, Soil Sci. Soc. Am. Journal, 69: 1026-1035. 
El-Gohary, M. A. 1996. A comparative study of deterioration causes and methods of conservation and maintenance of stone monuments in situ "An applied study on Remiss II temple in Abydos and Nektenbo II temple in Bahbit El-Heggara", MA thesis, Cairo Univ.

El-Gohary, M. A., 2004. Behavior of Lime mortar treated with some types of Paraloid after some cycles of artificial weathering, $4^{\text {th }}$ conference on capitals and great cities in Egypt along history: Studies in history, archaeology, restoration, tourism, geography and environment, Cairo Univ., Al Fayoum branch, Egypt, 148-163.

El-Gohary, M. A., 2008. Air Pollution and Aspects of Stone Degradation "Umayyed Liwān - Amman Citadel as a Case Study”, Journal of Applied Sciences Research, 4, (6): 669-682.

EL-Gohary, M. A., 2009. Characterization of bricks used in the external casing of roman bath walls "Gadara-Jordan", Int. Journal of Mediterranean Archaeology and Archaeometry, 9, (2): 1-19.

EL-Gohary, M. A., 2010. Investigation on limestone weathering of El-Tuba minaret as a case study-El-Mahalla, Egypt: A case study, Article in press in International Journal of Archaeology and Archeometry, 10 (1).

El-Metwally, A. A. and Ramadan, A. B., 2005. The role of air pollutants and sewage waste in acceleration of degradation of the Islamic cultural heritage of Cairo, Comparative risk assessment and environmental decision making, Vol. 38, Part 3, Springer, Netherlands, 363-370.

El-Shazly, E. M., 1954. Rock of Aswan area, Ministry of commerce and industry, Cairo, Egypt.

Fassina, V., 1991. Atmospheric pollutants responsible for stone decay. Wet and dry surface deposition of air pollutants on stone and the formation of black scabs. In Zezza, F. (ed.) Weathering and Air pollution, Bari, Italy, pp. 67-86.

Gilkes, R. J., Suddhiprakarn, A., and Armitage, T. M., 1980. Scanning Electronic Microscope morphology of deeply weathering Granite, Clays and Clay Minerals, 28, (1): 29-34.

Guven, N., Lafon, G. M. and Lee, L. J., 1982. Experimental hydrothermal alteration of Albite to clay preliminary results. In Van Olphen, H. and Veniale, F. (eds.) International clay conference, Elsevier, Amsterdam, 494-495.

KikUChi, H. I. K., Mito, Y., Baba, M., Sadahiro, T. and Nishibayashi, M., 1998. Prediction of properties change of cretaceous granitic rocks, kitakyushu granite, by the freezing and thawing, the geotechnics of hard soils soft rocks, Proceedings of the second international symposium on hard soils soft rocks Naples, 537-544.

HuAng, W. H., 1974. Stabilities of Kaolinite and Halloysite in relation to weathering of Feldspars and Nepheline in aqueous solution, American Mineralogist, 59: 365-371.
Jolicceur, S., Ildefonse, P. and Bouchard, M., 2000. Kaolinite and gibbsite weathering of biotite within saprolites and soils of central Virginia, Soil Sci. Soc. Am. J., 64: 1118-1129.

KeLleR, W. D., 1970. Environmental aspects of clay minerals, Sediment. Petrol., 40: 788-813.

KLein, C. and Hurlbt, C. S. JR, 1985. Manual of mineralogy, $20^{\text {th }}$ Ed., NY.

Lal Gauri, K. and Yerrapragada, S. S., 1996. Our recent studies on decay and preservation of stone objects. in Dhawan, S. (ed.). Recent trend in the conservation of art heritage, Delhi: 300-311.

LeE, C. H., Chor S. W. and SuH, M., 2003. Natural deterioration and conservation treatment of the granite standing Buddha of Daejosa Temple, Republic of Korea, Geotechnical and geological engineering, 21 (1): 63-77.

Liritzis, I., Sideris, C., Vafiadou, A. and Mitsis, J., (2008a). Mineralogical, petrological and radioactivity aspects of some building material from Egyptian Old Kingdom monuments, Journal of Cultural Heritage, 9: 1-13.

Liritzis, I, Kitis, G., Galloway, R. B., Vafiadou, A., Tsirliganis, N. C. and Polymeris, G. S. (2008b). Probing of luminescence dating of archaeologically significant carved rock types, Mediterranean Archaeology and Archaeometry, 8, (1): 61-79.

Lodding, W. and STURM, E., 1968. Weathering and orientation in Triassic clay sediments of New Jersey, Clays and Clay Minerals, 16: 179-186.

McKinley, J. M., Curran, J. M. and Turkington, A. V., 2001. Gypsum formation in non-calcareous building sandstone: a case study of Scrabo sandstone, Earth surface and landform, 26: 869-875.

Murakami, T., Ito, J. I., Utsunomiya, S., Kasama, T., Kozai, N. and OHNUKI, T., 2004. Anoxic dissolution processes of biotite: implications for Fe behavior during Archean weathering, Earth and Planetary Science Letters, 224: 117-129.

Murakami, T., UtsunomiYa, S., Yoкoyama, T. and Kasama, T., 2003. Biotite dissolution processes and mechanisms in the laboratory and in nature: Early stage weathering environment and vermiculitization, American Mineralogist, 88: 377-386.

Murray, H. H., 1953. Genesis of clay minerals in some Pennsylvanian Shale of Indiana and Illinois. $2^{\text {nd }}$ national conference on clays and clay minerals, University of Missouri, 47-67.

Newman, A. C. and Brown, G., 1987. The chemical constitution of clays, In Newman, A. C. D. (ed.). Chemistry of clays and clay minerals, Longman, UK, p. 22.

Newman, A. C. D., 1987. The interaction of water with clay mineral surface, In Newman, A. C. D. (ed.). Chemistry of clays and clay minerals, Longman, UK, 249-252. 
O'Brien, P. J., Bell, E., Santamari, S. P., Boyland, P. and Cooper, T. P., 1995. Role of mortar in the decay of granite, Science of the total environment, 167: 103-110.

OluIER, C., 1984. Weathering, Longman Group Ltd., London.

Parham, W. E., 1969. Formation of Hallocite from feldspar: low temperature, artificial weathering versus natural weathering, Clays and Clay Minerals, 17: 13-22.

Power, E. T. and SMITH, B. J., 1994. A comparative study of deep weathering products: case studies from Ireland, Corsica and Southeast Brazil. Rock weathering and landform evolution, John Wiley and Sons, p. 20-40.

Robert, M., Vergés-Belmin, V., Jaunet, A. M., Hervio, M. and Bromblet, P. H., 1992. Misen évidence de deux microsystèmes d' alteration (chimique et physique) dans les monuments en granit (Bretgane), in Delgado, J., Henriques, F., Telmo, F. (eds). VII international symposium on deterioration and conservation of stone, Lisbon, Volume. 1: 129-139.

SABbioni, C., 1995. Contribution of atmospheric deposition to the formation of damage layer, Science of the total environment, 16749-55.

SAYIN, A. S., 2007. Origin of Kaolin Deposits: Evidence from the Hisarcik (Emet-Kütahya) deposits, Western Turkey, Turkish Journal of Earth Sciences, 16: 77-96.

SCHEFFER, M. J. and LESAK, J. D., 2000. Natural weathering of granite: a case study, Dimension stone cladding: design, construction, evaluation and repair, ASTM International.

Schiavon, N., 1996. Soiling of urban granite I: Micro-fabrics and mineralogical aspects, Degradation and conservation of granitic rocks in monuments, European Commission, Brussels, 307-312.

SEASE, C., 1992. A conservation manual for the field archaeologist, $2^{\text {nd }}$ Edition, USA.

SEgalen, P., 1971. Metallic oxides and hydroxides in soils of the warm and humid areas of the world: formation, identification, evaluation, Soil and tropical weathering, Proceeding of the Bandung Symposium, Unesco, Paris, 15-24.

Shimoda, S., 1969. New data for Tosudite, Clays and Clay Minerals, 17: 179-184.

Sidraba, I., Krage, L., Igaune, S. And Vitina, I., 2002. Corrosion and restoration of travertine and Granite in the freedom monument (Riga, Latvia), In Prikryl, R. and Viles, H. (eds.) Understanding and managing of stone decay, Charles Univ., Prague, 275-284.

Smith, J. V., 1998. Atmospheric weathering and silica-coated feldspar: Analogy with zeolite molecular sieves, granite weathe- ring, soil formation, ornamental slabs, and ceramics, Proc. Natl. Acad. Sci, 95, USA, 3366-3369.

Środoń, J., 1999. Nature of mixed-layer clays and mechanisms of their formation and alteration, Annu. Rev. Earth Planet. Sci., 27: 19-53.

Stierman, D. J. And Healy, J. H., 1984. A study of the depth of weathering and its relationship to the mechanical properties of near-surface rocks in the Mojave desert, Pure and Applied Geophysics, 122, (2-4): 425-439.

Sтоскs, D. A., 2003. Experimental in Egyptian archaeology: stoneworking technology in ancient Egypt, London, 75-76.

Suggate, R. P., Waiters, W. A., 1991. Inside-out weathering of boulders in glacial outwash gravel, New Zealand Journal of Geology and Geophysics, 34: 93-97.

Sweevers, H., Peeters, A. and Van Grieken, R., 1995. Weathering of Leinster granite under ambient atmospheric conditions, Science of the total environment, 167: 73-85.

Szadorski, J., Weber, J., Lorenc, M. ANd Kocowicz, A. 2007. Weathering products of plutonic acid rocks ranging from alkali feldspar granite to tonalite, located in Lower Silesia, SW Poland, Geophysical Research Abstracts, Vol. 9: 1-2.

TAYLOR, R. M., 1987. Non-silicate oxides and hydroxides, In Newman, A. C. D. (ed.). Chemistry of clays and clay minerals, Longman, UK, 141.

Velde, B. and Meunier, A., 1987. Petrologic phase equilibria in natural clay systems, In Newman, A. C. D. (ed.). Chemistry of clays and clay minerals, Longman, UK, 444.

White, A. F. and Brantley, S. L., 2003. The effect of time on the weathering of silicate minerals: why do weathering rates differ in the laboratory and field?, Chemical Geology, 202, 479-506.

Whitman, R., 1992. Hatshepsut speak to me, Wayne state university, USA.

WINKLER, E. M., 1997. Stone in architecture: properties, durability, $3^{\text {rd }}$ Edition, Berlin.

ZaLbA, P. E., 1982. Scan Electron Micrographs of clay deposits of Buenos Aires province, Argentina, In Van Olphen, H. and Veniale, F. (eds.) International clay conference, Elsevier, Amsterdam, 513-528.

\section{Internet sites}

Park, H. D., Shin, G. H. and Chang, Y. S. Three Dimensional Modeling and Visualization of Weathered Rock Surface, School of Civil, Urban and Geosystem Engineering, Seoul National University, Seoul, South Korea, [http://www.isprs. org/proceedings/XXXIV/5-W3/download/park.pdf, 20/3/2010] 